\title{
THE IGM ANTIBODY RESPONSE IN RUBELLA DURING PREGNANCY
}

\author{
J. Desmyter, Mary Ann South and W. E. Rawls \\ Rega Institute, University of Leuven, Leuven, Belgium, and \\ Baylor College of Medicine, Houston, Texas, USA
}

VesikARI AND VAheri (1968) and Best, Banatvala and Watson (1969), working mainly with non-pregnant cases of acute rubella, studied the sedimentation profile of rubella haemagglutination-inhibiting (HI) antibodies in sucrose density gradients. Rubella $\mathrm{HI}$ antibodies corresponding to heavy immunoglobulins IgM were found exclusively in serum collected during the first month after the onset of symptoms. Macrae (1969) expressed doubts about the practicability of this complex method for diagnosis of recent infection. The validity of the method has been questioned by Newman, Horta-Barbosa and Sever (1969) who found overlapping of IgG into the IgM-containing fractions of serum from children with congenital rubella.

In experiments started before the appearance of the above reports, we attempted to identify the rubella virus-specific immunoglobulins by density gradient centrifugation of serum from pregnant women. Under the conditions presented in this report, IgM antibodies to rubella virus could be identified by examining a single fraction which was found not to be contaminated by IgG. As in non-pregnant subjects, rubella virus antibody activity was detected in the IgM fraction for only the 1st $\mathrm{mth}$ after the onset of the rubella rash.

\section{MATERIALS AND METHODS}

Sedimentation analysis. A density gradient was prepared by layering $1.5 \mathrm{ml}$ amounts of 40,25 and 10 per cent. (w/v) solutions of sucrose in phosphate-buffered saline in $5 \mathrm{ml}$ lusteroid tubes (modified after Fudenberg and Kunkel, 1957). The gradient was equilibrated by diffusion overnight in the refrigerator. A $0.5 \mathrm{ml}$ volume of serum diluted 1 in 4 in phosphatebuffered saline was placed on top of the gradient. This dilution of serum was used since it appeared from preliminary tests to give a better separation of the various immunoglobulins than undiluted serum. The tubes were centrifuged for $18 \mathrm{hr}$ at 35,000 r.p.m. in a Beckman Spinco model L2 centrifuge with SW 39 or SW 50.1 rotors. Fractions were collected by puncturing the bottom of the tube. Six fractions of $0.8 \mathrm{ml}$ each were collected. The density of the different fractions was measured in an Abbe refractometer and a linear gradient was obtained (figure, upper graph).

IgM and IgG measurements. The presence and the concentration of IgM and IgG were measured in the different fractions by single radial immunodiffusion in commercial " immunoplates " (Hyland Laboratories, Los Angeles, California) containing specific antiserum against either human IgG or IgM. No attempt was made to detect IgA, IgD or IgE in the fractions or to define rubella virus antibody in these immunoglobulins. The antibody in the fractions containing the IgM and IgG was labelled correspondingly.

Rubella serology. Haemagglutination-inhibition tests (Stewart et al., 1967) were performed as described by Rawls (1970) by a microtitre method with goose or pigeon red blood

Received 6 July 1970; accepted 8 Aug. 1970.

J. MED. MICROBIOL.-VOL. 4 (1971) 
cells at $p H$ 6.2. Kaolin pretreatment was omitted on sera tested by density-gradient centrifugation, but anti-bird haemagglutinins were removed by mixing $0.2 \mathrm{ml}$ of serum with $0.6 \mathrm{ml}$ of phosphate-buffered saline and $0.1 \mathrm{ml}$ of 50 per cent. bird erythrocyte suspension, and keeping the mixture for $1 \mathrm{hr}$ at $4^{\circ} \mathrm{C}$. The erythrocytes were pelleted by centrifugation and the supernatant was layered on to the sucrose gradient. Gradient fractions were tested without further treatment. Starting dilutions in the HI test were 1 in 8 or 1 in 10. Serial fractions from the same density gradient were tested simultaneously. Neutralising antibodies to rubella virus were assayed as described by Rawls, Desmyter and Melnick (1967).

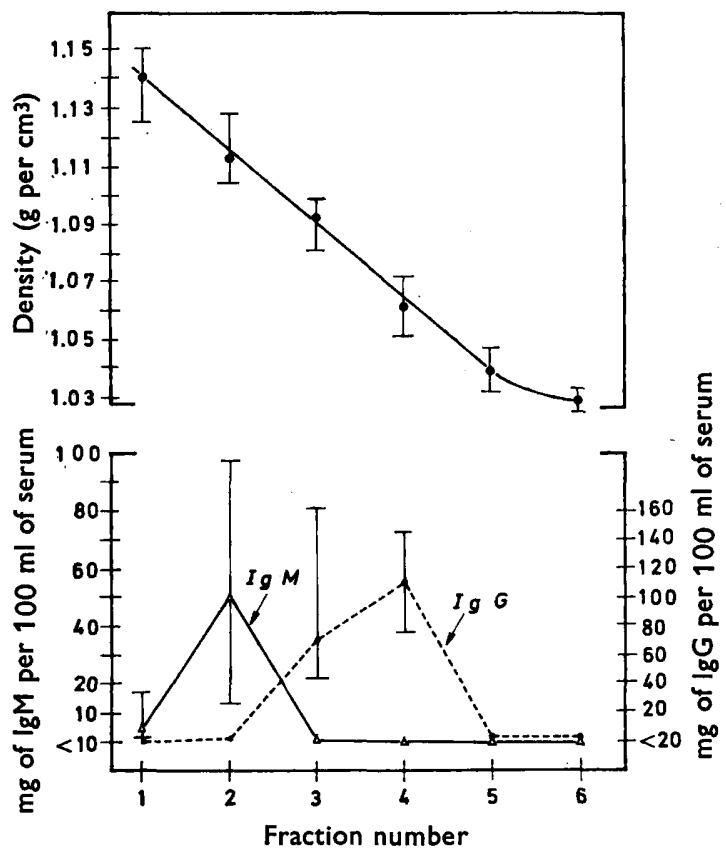

FIGURE.-Distribution of IgM and IgG after sucrose density-gradient centrifugation. Mean values and range of concentrations obtained with serum specimens from 12 pregnant women are shown (lower part). The densities of each of the six fractions of $0.8 \mathrm{ml}$ (mean values and range) attest to the linearity of the gradient (upper part).

\section{RESULTS}

\section{Distribution of immunoglobulins $\operatorname{Ig} M$ and $\operatorname{Ig} G$ and non-specific inhibitor of rubella virus haemagglutinin in sucrose gradients}

Sera from 12 pregnant women were used to examine the distribution of IgG and $\operatorname{IgM}$ in the six fractions of the gradient (figure, lower graph). IgM was present in fraction 2 of all sera, and was not found in fractions 3-6. IgG was present in fractions 3 and 4 of all sera. Five human sera, negative for rubella antibodies by both $\mathrm{HI}$ and neutralisation tests, were used to determine the fraction that contained the non-specific inhibitor of rubella haemagglutination (Stewart et al.). The inhibitor was recovered exclusively from the top of the gradient (fraction 6). It was concluded that the simplest scheme for demonstration of rubella IgM and IgG antibodies by density-gradient centrifugation 
would consist of $(a)$ omission of kaolin pretreatment, or any similar pretreatment for removal of inhibitor; $(b)$ the collection of only six fractions; $(c)$ testing

TABLE I

Rubella HI antibodies in serum of pregnant women with rubella

\begin{tabular}{|c|c|c|c|c|}
\hline \multirow{2}{*}{$\begin{array}{c}\text { Case } \\
\text { no. }\end{array}$} & \multirow{2}{*}{$\begin{array}{l}\text { Days after } \\
\text { onset of } \\
\text { illness }\end{array}$} & \multicolumn{3}{|c|}{ Haemagglutination-inhibiting antibody titre in } \\
\hline & & whole serum & IgM fraction & IgG fraction \\
\hline 1 & $\begin{array}{l}1 \\
5\end{array}$ & $\begin{array}{r}20 \\
>640\end{array}$ & 32 & $\dddot{512}$ \\
\hline 2 & $\begin{array}{l}2 \\
7\end{array}$ & $\begin{array}{r}80 \\
>640\end{array}$ & $\begin{array}{l}32 \\
\ldots\end{array}$ & $\begin{array}{l}128 \\
\ldots\end{array}$ \\
\hline 3 & 6 & $>640$ & 64 & 512 \\
\hline 4 & $\begin{array}{r}1 \\
15\end{array}$ & $\begin{array}{r}<10 \\
>640\end{array}$ & $\begin{array}{r}<8 \\
32\end{array}$ & $\begin{array}{l}<8 \\
128\end{array}$ \\
\hline 5 & $\begin{array}{l}1 \\
7\end{array}$ & $\begin{array}{r}20 \\
>640\end{array}$ & $\begin{array}{r}<8 \\
64\end{array}$ & $\begin{array}{r}32 \\
>1024\end{array}$ \\
\hline 6 & $\begin{array}{l}2 \\
9\end{array}$ & $\begin{array}{r}<10 \\
320\end{array}$ & $\ddot{16}$ & $\ldots$ \\
\hline 7 & $\begin{array}{r}7 \\
12\end{array}$ & $\begin{array}{l}1280 \\
1280\end{array}$ & $\begin{array}{l}32 \\
32\end{array}$ & $\begin{array}{l}32 \\
64\end{array}$ \\
\hline 8 & $\begin{array}{l}14 \\
28\end{array}$ & $\begin{array}{r}80 \\
>640\end{array}$ & ‥ & $\dddot{256}$ \\
\hline 9 & $\begin{array}{l}21 \\
36\end{array}$ & $\begin{array}{l}320 \\
320\end{array}$ & $\begin{array}{l}64 \\
16\end{array}$ & $\begin{array}{l}128 \\
256\end{array}$ \\
\hline 10 & $\begin{array}{l}1 \\
6\end{array}$ & $\begin{array}{r}<10 \\
640\end{array}$ & $\dddot{128}$ & $\dddot{256}$ \\
\hline 11 & $\begin{array}{l}2 \\
9\end{array}$ & $\begin{array}{r}20 \\
>640\end{array}$ & $\begin{array}{r}<10 \\
80\end{array}$ & $\begin{array}{r}<10 \\
40\end{array}$ \\
\hline 12 & $\begin{array}{l}4 \\
9\end{array}$ & $\begin{array}{r}160 \\
>640\end{array}$ & $\begin{array}{l}10 \\
40\end{array}$ & $\begin{array}{r}<10 \\
40\end{array}$ \\
\hline 13 & $\begin{array}{r}3 \\
17\end{array}$ & $\begin{array}{r}40 \\
640\end{array}$ & $\begin{array}{r}<10 \\
20\end{array}$ & $\begin{array}{r}<10 \\
20\end{array}$ \\
\hline 14 & 21 & 1280 & 20 & 80 \\
\hline 15 & $\begin{array}{r}1 \\
14\end{array}$ & $\begin{array}{r}<10 \\
160\end{array}$ & $\begin{array}{r}<8 \\
16\end{array}$ & $\begin{array}{l}<8 \\
128\end{array}$ \\
\hline 16 & $\begin{array}{r}7 \\
20\end{array}$ & $\begin{array}{l}640^{*} \\
640^{*}\end{array}$ & $\begin{array}{r}160 \\
40\end{array}$ & $\begin{array}{l}640 \\
640\end{array}$ \\
\hline 17 & $\begin{array}{l}1 \\
6\end{array}$ & $\begin{array}{r}<10 \\
320\end{array}$ & $\begin{array}{r}<10 \\
320\end{array}$ & $\begin{array}{r}<10 \\
80\end{array}$ \\
\hline
\end{tabular}

* Neutralising antibody titre on day 7 was 32 , on day 20,128 .

a single fraction (fraction 2) for rubella IgM antibodies; and (d) testing a single fraction (fraction 4) for rubella IgG antibodies. 


\section{Rubella IgM antibodies in pregnant women with rubella}

Sera from 17 pregnant women with clinical rubella were examined for the presence of specific IgM and IgG antibodies. The sera were obtained during the first trimester of pregnancy. The clinical diagnosis of rubella was confirmed by a significant rise of whole serum HI antibody whenever acute and convalescent sera were obtained at appropriate intervals (table I). In ten cases, serum was obtained during the first 3 days of illness; five had no demonstrable antibody, four had antibody titres of 20 or 40 , and one a titre of 80 . All sera taken at a later date had titres in excess of 40 . Rubella IgM antibodies were detected in all sera with whole-serum antibody titres exceeding 40 . Rubella IgG antibodies were present in all sera containing IgM antibodies. In case 9, the first serum was obtained 21 days after the rash and a significant rise in antibody titre could not be demonstrated. However, IgM antibody was present, suggesting a recent infection. The same was true for cases 7 and 16, where maximum levels of $\mathrm{HI}$ antibody were attained by day 7 ; in case 16 , a significant rise of neutralising antibody was detected. Rubella IgM antibody was found as late as day 36 in one case (case 9), but was not demonstrable in serum taken $34,35,41,55$ and 120 days after the onset of illness in other patients (not shown in table I).

\section{Absence of rubella IgM antibodies in pregnant women without rubella, and in women delivered of infants with congenital rubella}

Eight women in early pregnancy were suspected of having rubella. However, the clinical picture was indecisive and a specific antibody rise could not be demonstrated. Rubella IgM antibody was not found in serum specimens from these women (table II). Eight other women were bled after the birth of an infant with proven congenital rubella. In most instances, serological evidence of rubella had been obtained during pregnancy. With one exception (case 8), specific IgM antibody was absent from the serum (table III). These results indicate that the IgM antibody response to rubella infection in pregnancy is characterised by early appearance after the onset of clinical symptoms and disappearance about $1 \mathrm{mth}$ later. There does not appear to be any modification of the IgM response by the prolonged carriage of a chronically infected foetus in most cases. There are, however, exceptions (table III, case 8).

\section{DisCUSSION}

Using the methods of inactivation by 2-mercaptoethanol and density-gradient sedimentation, Schluederberg (1965) demonstrated the value of IgM antibody determinations in differentiating recent from past infections and in distinguishing the primary from the secondary antibody response in measles, mumps and coxsackie virus infections. Svehag and Mandel (1964) observed a prolonged IgM antibody response with live poliovirus as compared with killed virus, and Lehrich, Kassel and Rossen (1966) found the same with adenoviruses. These 
TABLE II

Rubella HI antibodies in serum of pregnant women without rubella

\begin{tabular}{|c|c|c|c|c|}
\hline \multirow{2}{*}{$\begin{array}{c}\text { Case } \\
\text { no. }\end{array}$} & \multirow{2}{*}{$\begin{array}{l}\text { Days after } \\
\text { onset of } \\
\text { illness }\end{array}$} & \multicolumn{3}{|c|}{ Haemagglutination-inhibiting antibody titre in } \\
\hline & & whole serum & IgM fraction & IgG fraction \\
\hline 1 & $\begin{array}{r}1 \\
24\end{array}$ & $\begin{array}{l}20 \\
40\end{array}$ & $\begin{array}{l}<10 \\
<10\end{array}$ & $\begin{array}{l}<10 \\
<10\end{array}$ \\
\hline 2 & $\begin{array}{r}4 \\
17\end{array}$ & $\begin{array}{l}80 \\
80\end{array}$ & $\dddot{<8}_{8}$ & $\dddot{512}$ \\
\hline 3 & $\begin{array}{r}4 \\
21\end{array}$ & $\begin{array}{l}40 \\
40\end{array}$ & $\dddot{<8}$ & $\dddot{32}$ \\
\hline 4 & $\begin{array}{r}4 \\
20\end{array}$ & $\begin{array}{l}<10 \\
<10\end{array}$ & $\begin{array}{c}<10 \\
\ldots\end{array}$ & $\begin{array}{c}<10 \\
\ldots\end{array}$ \\
\hline 5 & $\begin{array}{r}7 \\
24\end{array}$ & $\begin{array}{l}80 \\
80\end{array}$ & $\dddot{c}_{8}$ & $\dddot{6}_{64}$ \\
\hline 6 & 20 & 80 & $<8$ & 8 \\
\hline 7 & $\begin{array}{r}4 \\
21\end{array}$ & $\begin{array}{l}40 \\
40\end{array}$ & $\begin{array}{l}<10 \\
<10\end{array}$ & $\begin{array}{l}20 \\
10\end{array}$ \\
\hline 8 & $\begin{array}{r}7 \\
21\end{array}$ & $\begin{array}{l}320 \\
160\end{array}$ & $\begin{array}{l}<10 \\
<10\end{array}$ & $\begin{array}{l}80 \\
80\end{array}$ \\
\hline
\end{tabular}

TABLE III

Rubella HI antibodies in serum of mothers who had given birth to an infant with congenital rubella

\begin{tabular}{c|c|c|c|c}
\hline \multirow{2}{*}{$\begin{array}{c}\text { Case } \\
\text { no. }\end{array}$} & $\begin{array}{c}\text { Days after } \\
\text { birth }\end{array}$ & \multicolumn{3}{|c}{ Haemagglutination-inhibiting antibody titre in } \\
\cline { 3 - 5 } & & whole serum & IgM fraction & IgG fraction \\
\hline 1 & 12 & 80 & $<8$ & 16 \\
& 55 & 40 & $\ldots$ & $\ldots$ \\
2 & 1 & 80 & $<8$ & 16 \\
& 45 & 640 & $<8$ & 8 \\
3 & 0 & $>40$ & $<8$ & 32 \\
4 & 3 & 640 & $<8$ & 16 \\
5 & 9 & 1280 & $\ldots 8$ & $\ldots \%$ \\
& 14 & 640 & $<8$ & $\ldots$ \\
6 & 3 & 640 & $<8$ & 64 \\
& 4 & 640 & $<8$ & 256 \\
7 & 30 & 320 & $<8$ & 8 \\
8 & 0 & 640 & $<8$ & 8 \\
& 60 & 40 & 32 & 128 \\
\hline
\end{tabular}


authors concluded that persistence of the viral antigen was responsible for the continuing synthesis of IgM antibody.

Vesikari and Vaheri (1968) and Best et al. (1969), working with densitygradient centrifugation, described a specific rubella IgM antibody response demonstrable until the $3 \mathrm{rd}$ or 4 th wk after the onset of symptoms. In our series of 17 pregnant women, the findings were similar. IgM antibody was found in 21 serum specimens obtained during the first month after the onset of symptoms, and in all sera with a total antibody titre greater than 40 . The latter restriction probably represents the limit of sensitivity of our assay. IgM antibodies were absent in five subjects from whom serum was obtained later than $1 \mathrm{mth}$ after infection. They were also absent in seven out of eight mothers who had given birth to babies with congenital rubella. Therefore, the presence of a persistently infected foetus does not seem to affect significantly the duration of the maternal IgM antibody response to the virus.

One mother did have IgM antibody after the birth of her infected infant (table III, case 8), but it is difficult, from the present data, to assess the importance of this. Using an immunofluorescence method, Baublis and Brown (1968) found IgM antibody in two out of three mothers who had given birth to infants with congenital rubella, and in two out of four women with normal infants. The immunofluorescence and density centrifugation methods need further comparative evaluation.

Loss of antibody titre in serum after treatment with 2-mercaptoethanol has also been used as a method of detecting IgM antibodies in rubella (Banatvala et al., 1967; Cooper et al., 1969). The technique is much simpler than the separation of immunoglobulins by density-gradient centrifugation, but our experience (unpublished), as well as that of others (Banatvala et al.), suggests that it is less sensitive and less reliable for the firm diagnosis required in pregnancy. For example, Cooper et al., using a four-fold decrease in antibody titre after 2-mercaptoethanol treatment as evidence for the presence of IgM antibody, found only 23 per cent. of patients to have IgM antibody 9-15 days after the appearance of the rash. Table I shows that IgG antibody as well as IgM is measurable in gradient fractions soon after patients' recovery from illness, and that the IgG antibody comprises the larger fraction of the antibody activity. Therefore, reduction of total antibody activity by as much as 75 per cent. after 2-mercaptoethanol treatment would seem to be unlikely, although IgM antibody activity would be readily detected by density-gradient centrifugation.

The data shown in the figure and the absence of rubella IgM antibody in sera collected later than $1 \mathrm{mth}$ after the onset of illness, or from persons without recent infection, strongly support our contention that IgG did not significantly contaminate the IgM fraction obtained by sucrose density-gradient centrifugation. This difference between our results and those of Newman et al. (1969) could be due to our diluting the serum before layering it on to the gradient. Like Best and Banatvala (1969), we obtained unsatisfactory separation with undiluted serum. Alternatively, the immunoglobulins of infants with congenital rubella, examined by Newman et al., may differ in their properties from those of normal adults (Sever and White, 1968). 
The consistent finding of rubella IgM antibody accords with the classical view that clinical rubella and a significant antibody rise represent primary experience with the virus. Finally, it has been possible to standardise and simplify rubella IgM antibody determinations to the extent that a diagnosis of acute rubella infection in pregnancy can be confirmed or excluded by an $\mathrm{HI}$ antibody titration on a single density-gradient fraction of a single serum specimen, taken preferably between 1 wk and 3 wk after onset of symptoms.

\section{SUMMARY}

Sucrose density-gradient centrifugation was used for the study of serum IgM and IgG antibodies in rubella infection in early pregnancy. Seventeen women with proven rubella in the first trimester of pregnancy were tested and all were found to have an IgM antibody response to the virus. IgM antibody was present for $1 \mathrm{mth}$ following the onset of illness but not later, and it was absent in women who did not have acute rubella. With one exception, IgM antibodies were not found in women who had recently given birth to an infant with congenital rubella.

The technique involved the collection of six fractions from the density gradient. The second fraction, which contained IgM but was free from IgG, was tested for rubella antibody by means of an HI test. Examination of this one fraction from a single serum collected within $1 \mathrm{mth}$ of the onset of illness was sufficient to confirm or exclude a diagnosis of rubella.

This study was supported by research grants from the US Public Health Service, HE-05435 and AI-08227, Research Career Development Awards, 5-K3-AI-25943 (W. E. R.) and 1-K4-AI-23820 (M. A. S.) and a grant from the Belgian Medical Research Foundation (J. D.). Miss Cathryn Adams provided excellent assistance.

\section{REFERENCES}

Banatvala, J. E., Best, Jennifer M., Kennedy, Elizabeth A., Smith, Elizabeth E., ANd SPENCE, MARJorIE E. 1967. A serological method for demonstrating recent infection by rubella virus. $B r$. Med. J., 3, 285.

Baublis, J. V., AND BRown, G. C. 1968. Specific response of the immunoglobulins to rubella infection. Proc. Soc. Exp. Biol. Med., 128, 206.

Best, Jennifer M., ANd Banatvala, J. E. 1969. Serological tests for rubella. Lancet, 2, 546.

Best, Jennifer M., Banatvala, J. E., AND Watson, D. 1969. Serum IgM and IgG responses in postnatally acquired rubella. Lancet, 2,65 .

Cooper, L. Z., Matters, Barbara, Rosenblum, Jean K., and Krugman, S. 1969. Experience with a modified rubella hemagglutination inhibition antibody test. J. Amer. Med. Assoc., 207, 89.

Fudenberg, H. H., AND Kunkel, H. G. 1957. Physical properties of the red cell agglutinins in acquired hemolytic anemia. J. Exp. Med., 106, 689.

LEHRICH, J. R., KASEL, J. A., AND Rossen, R. D. 1966. Immunoglobulin classes of neutralizing antibody formed after human inoculation with soluble adenoviral antigens. $J$. Immun., 97, 654.

MACRAE, A. D. 1969. Serological tests for rubella. Lancet, 2, 220.

Newman, S., Horta-Barbosa, L., AND Sever, J. L. 1969. Serological tests for rubella. Lancet, 2, 432. 
Rawls, W. E. 1970. Rubella virus. In Manual of clinical microbiology, ed. by J. E. Blair, E. H. Lennette and J. P. Truant, Bethesda, Md., p. 528.

Rawls, W. E., Desmyter, J., AND Melnick, J. L. 1967. Rubella virus neutralization by plaque reduction. Proc. Soc. Exp. Biol. Med., 124, 167.

SCHLUEDERBERG, ANN 1965. Immune globulins in human viral infections. Nature, Lond., $205,1232$.

SeVer, J., AND White, L. R. 1968. Intrauterine viral infections. A. Rev. Med., 19, 471.

Stewart, G. L., Parkman, P. D., Hopps, Hope E., Douglas, R. D., Hamiton, Judith P., AND MeYer, H. M., JR 1967. Rubella-virus hemagglutination-inhibition test. New Engl. J. Med., 276, 554.

SvehaG, S. E., AND MANDEL, B. 1964. The formation and properties of poliovirusneutralizing antibody. II. $19 \mathrm{~S}$ and $7 \mathrm{~S}$ antibody formation: differences in antigen dose requirement for sustained synthesis, anamnesis, and sensitivity to X-irradiation. $J$. Exp. Med., 119, 21.

VESIKARI, T., AND VAHERI, A. 1968. Rubella: a method for rapid diagnosis of a recent infection by demonstration of the IgM antibodies. Br. Med.J., 1, 221. 